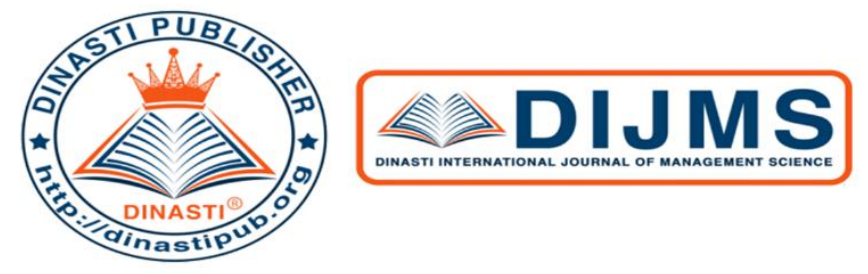

$+6281387654578$

$+6281387654578$

https://dinastipub.org/DIJMS (8)

dinasti-info@gmail.com G.

\title{
ANALYSIS OF SERVICE QUALITY AND BRAND IMAGE ON CUSTOMER SATISFACTION THROUGH PURCHASE DECISIONS AS INTERVENING VARIABLE (CASE STUDY E-COMMERCE SHOPEE AT VILLA GALAXY HOUSING RT 002)
}

\author{
Deviana Vierdwiyani ${ }^{1}$, Afriapollo Syafarudin ${ }^{2}$ \\ ${ }^{1)}$ Mercu Buana University, Bekasi, Indonesia \\ ${ }^{2)}$ Mercu Buana University, Bekasi, Indonesia
}

\begin{tabular}{|c|l|}
\hline $\begin{array}{c}\text { ARTICLE INFORMATION } \\
\text { Received: } 17^{\text {th }} \text { May } 2020 \\
\text { Revised: } 20^{\text {th }} \text { June } 2020 \\
\text { Issued: } 19^{\text {th }} \text { July } 2020\end{array}$ & $\begin{array}{l}\text { Abstract: This study aims to determine the effect of service } \\
\text { quality and brand image on purchasing decisions and } \\
\text { customer satisfaction in Shopee. This study also examines } \\
\text { the indirect effect of service quality and brand image on } \\
\text { customer satisfaction with purchasing decisions as a } \\
\text { mediating or intervening variable. The study was conducted } \\
\text { at RT 002 Villa Galaxy. The sample in this study was } \\
\text { Shopee customers with a purposive sampling method. The } \\
\text { number of respondents who participated in this study were } \\
\text { 100 respondents. Data collection was carried out through a } \\
\text { questionnaire with a Likert scale of 1-5. The method and } \\
\text { analysis tool is Partial Least Square (PLS) with Smart PLS } \\
\text { Software 3. The results of the study show that service } \\
\text { quality has a significant positive effect on purchasing } \\
\text { decisions, brand image has a significant positive effect on } \\
\text { purchasing decisions, service quality has a significant } \\
\text { positive effect on customer satisfaction, brand image } \\
\text { significant positive effect on customer satisfaction, } \\
\text { purchasing decisions significantly positive effect on } \\
\text { customer satisfaction, and purchasing decisions mediate the } \\
\text { effect of service quality and brand image on customer } \\
\text { satisfaction. Shopee can improve service quality and brand } \\
\text { image so that purchasing decisions and customer } \\
\text { satisfaction can be improved, through improved features } \\
\text { and application services. } \\
\text { Kata Kunci : service quality, brand image, purchasing } \\
\text { decisions, customer satisfaction, shopee }\end{array}$ \\
\hline
\end{tabular}

\section{INTRODUCTION}


Nowadays, the shopping style of Indonesian people began to shift. From conventional transactions, now our society prefers shopping through online platform. Head of the Central Statistics Agency (BPS) Suhariyanto also acknowledged that the phenomenon of online shopping is happening in Indonesia, and one of the factors is the rapid growth of ecommerce. There are hundreds of online shopping sites with various product groups ranging from electronics, clothing, health, to travel. The most popular platform are Tokopedia, Bukalapak, Lazada, Shopee, Traveloka. Shopee is an shopping online mobile application and website, headquartered in Singapore under the SEA Group which was founded in 2009 by Forrest Li. Because Shopee's mobile application and web are built according to the concept of global electronic commerce, Shopee is becoming one of the "5 most disruptive ecommerce startups" published by Tech In Asia. For consumers in Indonesia, according to a survey conducted in December 2017 by The Asian Parent, revealed that "for Indonesian mothers, Shopee is the first choice shopping platform (73\%), followed by Tokopedia (54\%), Lazada (51\%) and Instagram (50\%).

Table 1. Most Preferred Online Shopping Platform ( The Asian Parent 2017)

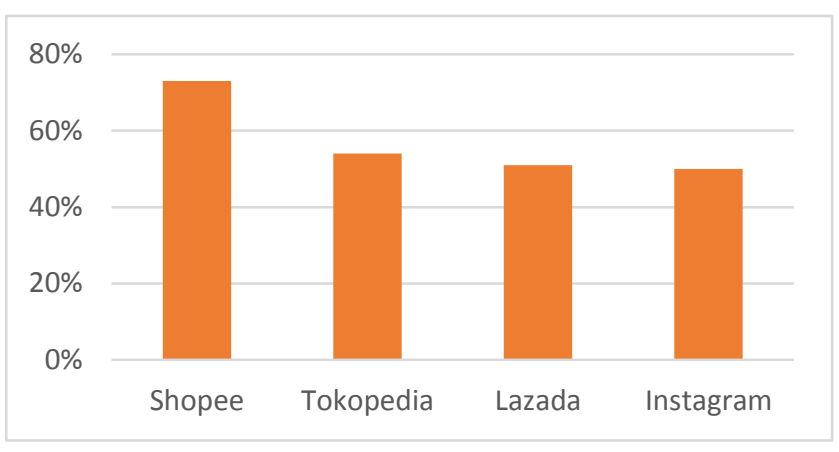

To find out the reason why people choose E Commerce as a place to shop nowadays, dailysocial also conducted a survey of 1240 respondents. From the results of a survey conducted by dailysocial. from the survey results, it can be seen that the quality of service and brand image are the variable that are considered by consumers in shopping online. Setiyaningrum and Hidayat (2016) conducted a study, of service quality and satisfaction ,in purchasing on a website, the results of this study found that the empathy dimension is the dimension of service quality, which determines the customer satisfaction who shops at online stores.

Hasan (2013) argues that a brand is interpreted as a combination of a name, sign, symbol or design to identify goods and services from a business or business group that is developed into a trademark and distinguish themselves from competitors, create influence and produce value for the attributes other products that provide identity and differentiation from competitors' products. Thus, brand image is defined as consumers 'perceptions and preferences towards brands as reflected by various brand associations that exist in consumers' memories. Although brand associations can occur in various forms, but can be divided into performance associations and imaginary associations related to brand attributes and strengths (Ratri, 2007: 47).In promotional activities, marketers must be able to create the right marketing content in accordance with needs and in accordance with established goals. As a campaign that aims to build a brand image, as well as the presentation of attractive advertisements in accordance with the characteristics of the product. 
This phenomenon is also in line with research conducted by Wibowo et al (2017) which states that brand image influence consumers in building their buying interest. From the description of the phenomena and findings of previous studies that have been described above, the author wants to analyze the factors that influence consumers on online purchasing decisions at Shopee.

The author is interested in conducting research with tittle "Analysis of Influence of Service Quality and Brand Image on customer satisfaction through customer purchasing decisions as a intervening variable (Case Study of E-Commerce Shopee) at Villa Galaxy Housing RT 002

\section{LITERATURE REVIEW}

Electronic commerce, also called e-commerce, is the use of communication networks and computers, to carry out business processes. A popular view of e-commerce is the use of the internet and computers with web browsers to buy and sell products. Kalakota and Winston (2003), stated that the definition of e-commerce is the delivery of goods, services, information, or payments through computer networks or through other electronic equipment, applications of technology leading to the automation of business transactions, tools that meet the desires of companies, consumers, and management to cut service costs (sevice costs) when improving the quality of goods and increasing the speed of shipping services, ecommerce also provides the ability to buy and sell goods, or service quality.

\section{Definition of Service Quality}

Parasuraman (1991) stated that service quality is an abstract construct and difficult to understand because of their 3 unique features related to services, namely intangibility, heterogeneity and inseparability of production and consumption. Kiew and Chee (2010) stated that service quality also involves the perception and expectations of the level of service provided to consumers to meet their needs. Service quality is also about the expectations of consumers in the service environment, the process and the output quality that they can see and feel for themselves.

Service quality can be known by comparing consumers' perceptions on the service, that they actually receive or obtain with the service that they actually expect or want, on the service that attributes by a company. The best service to customers and the level of quality , can be achieved by improving the service quality and by paying special attention to the service performance standards.

\section{Dimensions of Service Quality}

Lovelock and Wirtz (2007) state that the basic criteria of service, namely: physical form (Tangibles), which means the company's ability to show its existence to customers. Appearance and ability of the company's physical advice and infrastructure in the surrounding environment, reliability (Reliability), namely the company's ability to provide services as promised, responsiveness (Responsiveness), namely the company's ability to help customers and availability to serve customers and availability to serve customers with a good service, guarantee (Assurance), namely the ability of company employees to grow the trust of customers in the company and empathy (Empathy), which gives a sincere and individual attention that given to customers in the form of understanding customer desires. 
To create the good quality of customer service, surely need a good quality of service that perform by the employees. .

\section{Definition of Brand Image}

Hasan (2013) stated that a brand is interpreted as a combination of a name, sign, symbol or design to identify goods and services from a business or business group that is developed into a trademark and distinguishes itself from competitors, creates influence and produces special value for the company. Many also refer to as design, color, motion, or a combination of other product attributes that give identity and differentiation to competitors' products. Brand image is often used as extrinsic cues when consumers evaluate a product before deciding their intention to buy (Wang and Tsai, 2014: 28). In line with Kotler and Keller (2009: 334) who explained that brand image is an association that arises in the minds of consumers when remembering certain brands.

\section{Dimensions of Brand Image}

Brand image according to Kotler and Keller (2013) dimensions were: brand identity (physical identity), brand personality (brand personality), brand association (brand association), brand attitude and behavior, and brand benefit and competence (benefits and brand competency).

\section{The Definition of Purchasing Decisions}

Kotler (2008) stated that purchasing decisions are the final choice made by consumers in meeting their wants or needs. The purchasing decision-making process for everyone is basically the same, it's just that not all of these processes are carried out by consumers. According to Levy and Weitz (2011) purchasing decisions are the conversion of evaluations that have been carried out by consumers in order to make a purchase.

\section{Dimensions of Purchase Decisions}

According to Kotler and Keller (2012: 161) purchase decisions have dimensions namely: product selection, brand choice, supplier selection, number of purchases, determination of time of visit and payment method.

\section{Customer satisfaction}

\section{Definition of customer satisfaction}

Based on the definitional framework prepared by Giese and Cote (2000) cited by Tjiptono and Chandra (2011: 292), customer satisfaction is:

- Summary of various intensities of active responses. The type of effective response and intensity level that consumers might experience, that must be explicitly defined by the researcher, depending on the context of the research.

- Within a specific determination time and limited duration. The researcher must determine the determination time that is most relevant to the research problem and identify the possible duration of the response.

- Which is aimed at important aspects of product acquisition and / or consumption. The researcher must identify the research focus based on the research question or managerial problem being faced.

\section{Dimensions of Customer Satisfaction}


Things that can affect customer satisfaction can be seen from the size or dimensions of customer satisfaction according to Kotler (2011), namely:

1.Stay loyal

Satisfied consumers tend to be loyal or loyal. Consumers who are satisfied with the products they consume will have a tendency to repurchase from the same producer.

2.Buy the products offered

The desire to buy products or other food offered because of the desire to repeat good experiences and avoid bad experiences.

3. Recommend the product

Satisfaction is a factor that encourages positive word of mouth communication. This can be in the form of recommendations to other potential customers and say good things about the product and the company that provides the product.

4. Willing to pay more

Consumers tend to use price as a benchmark of satisfaction, when prices are higher consumers tend to think quality is higher too.

5. Give input or suggestions

Although the consumer's satisfaction has been achieved, consumers will always want to receive more, consumers will provide input or suggestions so that their desires can be achieved.

\section{RESEARCH METHODS}

The research method contains the type of research, sample and population or research subject, time and place of research, instruments, procedures and research techniques, as well as other matters related to the research method. This section can be divided into several subchapters, but it is not necessary to include the numbering.

\section{Research Structure}

Based on the aims and relevant literature, this study proposes a research model of the effects of service quality and brand image on customer satisfaction through purchase decisions as intervening variable ( case study e-commerce Shopee) at Villa Galaxy RT 002 and the model is showed in Figure 1.

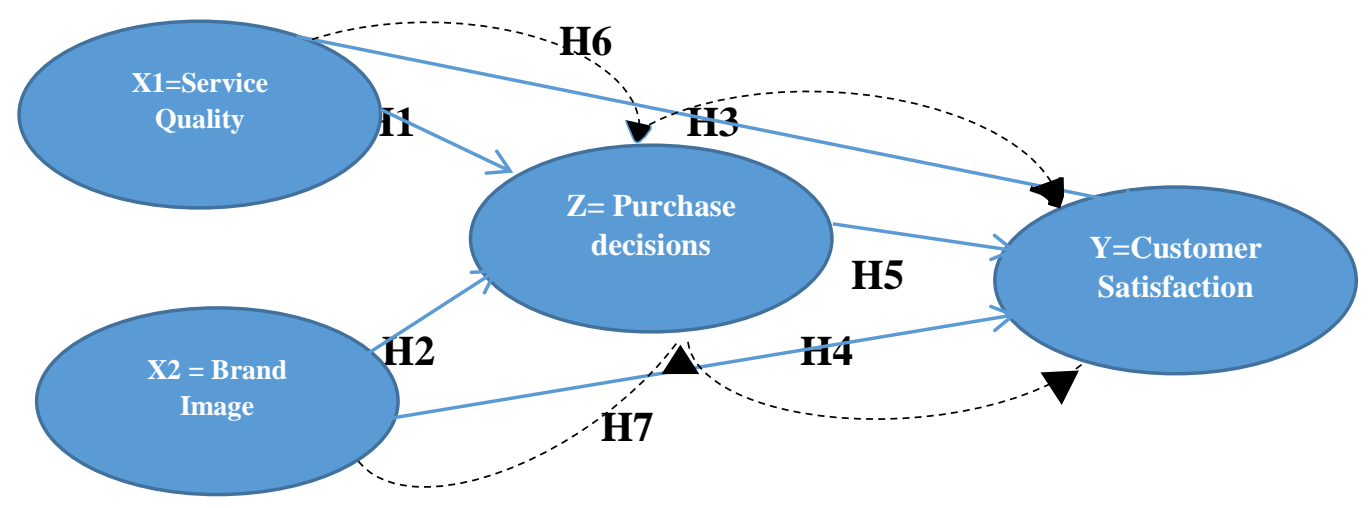

Figure 1. Methodology Framework 


\section{Research Hypotheses}

According the results drawn from literature review, the following hypotheses are proposed:

H1: Service quality has a positive and significant effect on purchase decisions.

$\mathrm{H} 2$ : Brand Image has a positive and significant effect on purchasing decisions

H3: Service Quality has a positive and significant effect on customer satisfaction

H4: Brand image has a positive and significant effect on customer satisfaction

H5: Purchasing decisions have a positive and significant effect on customer satisfaction

H6: Purchasing decisions can interfere the relationship between service quality and customer satisfaction.

H7: Purchasing decisions can interfere with the relationship between brand image and customer satisfaction.

\section{Research Subjects and Research Tools}

The study was conducted at RT 002 Villa Galaxy. The sample in this study was Shopee customers with a purposive sampling method. The number of respondents who participated in this study were 100 respondents. Data collection was carried out through a questionnaire with a Likert scale of 1-5. The method and analysis tool is Partial Least Square (PLS) with Smart PLS Software 3.In this study, the questionnaires was distribute to 100 respondents who had shopped at Shopee, who lives in Villa Galaxy Housing RT 002, with criteria : gender, age, and level of education. From the total 100 respondents there were 38 men or $38 \%$ and 62 women or $62 \%$. This indicates that Shopee applications are preferred by female consumers with a percentage reaching $62 \%$. Characteristics of respondents based on age produced data of 3 people under the age of 30 years or $3 \%, 87$ people aged $30-50$ years or $87 \%$, and 10 people aged over 50 years or $10 \%$. These characteristics indicate that the Shoppee is favored by the age group between 30- 50 years. Based on educational background there are 24 people with high school education or $24 \%$, and 76 people with undergraduate education or $76 \%$. This indicates that the Shopee application is preferred by respondents with a Bachelor's educational background

\section{FINDINGS AND DISCUSSION \\ Data Analysis Results}

\section{Outer Model Evaluation : Convergent Validity}

Convergent validity of the measurement model is assessed based on the correlation between item score / component score and construct score calculated by Partial Least Square - PLS. In this research, a loading factor limit of 0.50 will be used. if the loading factor value> 0.50 then convergent validity is fulfilled. The results using SmartPLS can be seen in table 2. Based on the table, the loading factor values obtained in the initial model have fulfilled convergent validity because all indicators have a loading factor value $>0.50$. 
Table 2.Loading Factor Value from Outer Loadings

\begin{tabular}{lcccc}
\hline & $\begin{array}{c}\text { X1= Service } \\
\text { quality }\end{array}$ & $\begin{array}{c}\text { X2=Brand } \\
\text { image }\end{array}$ & $\begin{array}{c}\text { Y=Customer } \\
\text { satisfaction }\end{array}$ & $\begin{array}{c}\text { Z=Purchase } \\
\text { decisions }\end{array}$ \\
\hline $\mathrm{X} 1.1$ & 0,896 & & & \\
$\mathrm{X} 1.2$ & 0,867 & & & \\
$\mathrm{X} 1.3$ & 0,853 & & & \\
$\mathrm{X} 1.4$ & 0,740 & 0,845 & & \\
\hline $\mathrm{X} 2.1$ & 0,781 & & \\
$\mathrm{X} 2.2$ & 0,914 & & \\
$\mathrm{X} 2.3$ & 0,774 & & \\
$\mathrm{X} 2.4$ & & & 0,760 & \\
\hline $\mathrm{Y} 1$ & & 0,741 & 0,752 \\
$\mathrm{Y} 2$ & & 0,837 & 0,709 \\
$\mathrm{Y} 3$ & & 0,829 & 0,709 \\
$\mathrm{Y} 4$ & & & 0,755 \\
\hline $\mathrm{Z} 1$ & & & \\
$\mathrm{Z} 2$ & & & \\
$\mathrm{Z} 3$ & & & \\
$\mathrm{Z} 4$ & & & & \\
\hline
\end{tabular}

\section{Discriminant validity}

Discriminant validity of the measurement model with reflexive indicators is assessed based on cross loading construct measurements. The model has good discriminant validity, if each loading value of each indicator of a latent variable has the greatest loading value compared with another loading value of other latent variables (Ghozali, 2008).

Table 3. Fornell Larcker Criterion

\begin{tabular}{lcccc}
\hline & $\begin{array}{c}\text { X1=Service } \\
\text { quality }\end{array}$ & $\begin{array}{c}\text { X2=Brand } \\
\text { image }\end{array}$ & $\begin{array}{c}\text { Y= } \\
\text { Customer } \\
\text { satisfaction }\end{array}$ & $\begin{array}{c}\mathbf{Z}= \\
\text { Purchase } \\
\text { decisions }\end{array}$ \\
\hline X1=Service quality & 0,841 & & & \\
X2=Citra Merk & 0,063 & 0,830 & & \\
Y=Kepuasan Pelanggan & 0,725 & 0,513 & 0,793 & 0,732 \\
Z=Purchase decisions & 0,608 & 0,418 & 0,729 & 0 \\
\hline
\end{tabular}


From the table above, can be seen that the value of the variable itself shows a greater number than the correlation between variables. Thus the discriminant validity requirements have been fulfilled.

\section{Average Variance Extracted (AVE)}

Discriminant validity can also be seen from the average variance extracted (AVE) value. The minimum AVE to state that the reliability of the indicator has been achieved is greater or equal to 0.50 , as shown below.

Table 4. AVE Average Variance Extracted

\begin{tabular}{lc}
\hline & $\begin{array}{c}\text { Average Variance } \\
\text { Extracted (AVE) }\end{array}$ \\
\hline X1= Service quality & 0,708 \\
X2= Citra Merk & 0,689 \\
Y= Customer satisfaction & 0,628 \\
$Z=$ Purchase decisions & 0,536 \\
\hline
\end{tabular}

Based on the test results on the average variance validity (AVE), each latent variable is greater than 0.50 . Means each latent variable meet the requirements of good discriminant validity

\section{Reliability Test}

\section{Composite Reliability}

The measurement of composite reliability were use to test the reliability of variables. Variables that have good reliability, can be demonstrated with a composite variable value> 0.60 .

Tabel 5. Composite Reliability

\begin{tabular}{lcc}
\hline & Cronbach's Alpha & Composite Reliability \\
\hline X1= Service quality & 0,862 & 0,906 \\
X2= Brand image & 0,854 & 0,898 \\
Y= Customer satisfaction & 0,802 & 0,871 \\
Z= Purchase decisions & 0,715 & 0,822 \\
\hline
\end{tabular}

Table 5 shows that the composite reliability and Cronbach's alpha are all above 0.70, means all constructs have good reliability.

\section{EVALUATION TEST MODEL}

Evaluation of the Inner R-Square Model 
The Changes of R-Square can be used to assess the effect of certain independent latent variables on the dependent latent variable, and whether it has a substantive effect (Ghozali, 2008).

\begin{tabular}{lc}
\multicolumn{2}{c}{ Table 6 . R-Square } \\
\hline & R Square \\
\hline Y= Customer satisfaction & 0,880 \\
$Z=$ Purchase decisions & 0,580 \\
\hline
\end{tabular}

In the table above , R-Square gives a construct value of Customer Satisfaction of 0.880 which means that the Effect of Service Quality and Brand Image and Purchase Decisions on Customer Satisfaction is $88 \%$. Whereas the construct value of the Purchasing Decision is 0.580 which means that the Effect of Service Quality and Brand Image to the Purchase Decision is $58 \%$.

\section{Hypothesis Testing}

Hypothesis testing is performed to determine the relationship between research variables, that carried out by the bootstrap method.

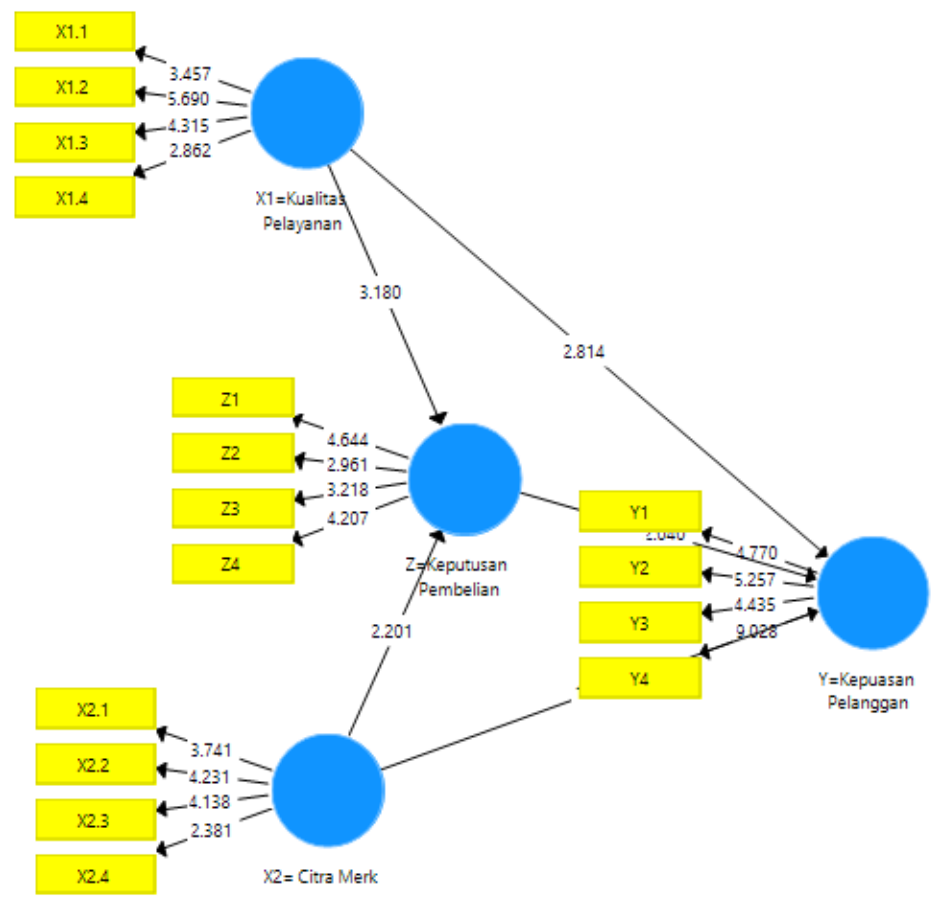

Figure 2. Bootstrap testing method and result

\section{Bootstrap Testing Method}

In Partial Least Square-PLS testing statistically, each hypothesized relationship is carried out using estimates. In this case the bootstrap method is performed on the sample. 


\section{Hypothesis Testing (T Statistic \& Path Coefficient)}

Table 7. Path Coefficient (Mean, STDEV, T-Values)

\begin{tabular}{lcccc}
\hline & $\begin{array}{c}\text { Original } \\
\text { Sample (O) }\end{array}$ & $\begin{array}{c}\text { Sample } \\
\text { Mean (M) }\end{array}$ & $\begin{array}{c}\text { Standard } \\
\text { Deviation } \\
(\text { STDEV) }\end{array}$ & $\begin{array}{c}\text { T Statistics } \\
(|\mathbf{O} / \mathbf{S T E V}|)\end{array}$ \\
\hline $\begin{array}{l}\text { X1= Service quality -> Z= Purchase } \\
\text { decisions }\end{array}$ & 0,637 & 0,603 & 0,200 & 3,180 \\
$\begin{array}{l}\text { X2= Brand image -> Z= Purchase } \\
\text { decisions }\end{array}$ & 0,459 & 0,458 & 0,208 & 2,201 \\
$\begin{array}{l}\text { X1= Service quality -> Y= Customer } \\
\text { satisfaction }\end{array}$ & 0,561 & 0,479 & 0,200 & 2,814 \\
$\begin{array}{l}\text { X2= Brand image -> Y= Customer } \\
\text { satisfaction }\end{array}$ & 0,417 & 0,380 & 0,232 & 1,996 \\
$\begin{array}{l}\text { Z= Purchase decisions -> Y= Customer } \\
\text { satisfaction }\end{array}$ & 0,313 & 0,334 & 0,153 & 2,040 \\
\hline
\end{tabular}

Following, the test results with bootstrapping from PLS analysis:

The relationship between Service Quality and Purchasing Decisions is significant with a T-statistic of 3.180> 1.96. The original sample value is positive that is equal to 0.637 which indicates that the direction of the relationship between Brand Image and Purchasing Decisions is positive so that hypothesis 1 is accepted.

The relationship between Brand Image and purchasing decisions is significant with Tstatistic of 2.201> 1.96. The original sample value is positive that is equal to 0.459 which shows that the direction of the relationship between Brand Image and the purchase decision is positive so that hypothesis 2 is accepted.

The relationship between Service Quality and Customer Satisfaction is significant with a T-statistic of 2.814> 1.96. The original sample value is positive that is 0.561 which shows that the direction of the relationship between Service Quality and Customer Satisfaction is positive so that hypothesis 3 is accepted.

The relationship between Brand Image and Customer Satisfaction is significant withTstatistics of 1.996> 1.96. The original sample value is positive that is equal to 0.417 which indicates that the direction of the relationship between Brand Image and Customer Satisfaction is positive so that hypothesis 4 is accepted.

The relationship between Purchasing Decisions and Customer Satisfaction is significant with a T-statistic value of 2.040> 1.96. While the original sample value is positive at 0.313 which indicates that the direction of the relationship between the Purchasing Decision and Customer Satisfaction is positive so that hypothesis 5 is accepted. 
Table 8. Indirect Effect

\begin{tabular}{lcccc}
\hline & $\begin{array}{c}\text { Original } \\
\text { Sample } \\
(\mathbf{O})\end{array}$ & $\begin{array}{c}\text { Sample } \\
\text { Mean (M) }\end{array}$ & $\begin{array}{c}\text { Standard } \\
\text { Deviation } \\
\text { (STDEV) }\end{array}$ & $\begin{array}{c}\text { T Statistics } \\
\text { (|O/STDEV|) }\end{array}$ \\
\hline $\begin{array}{l}\text { X1= Service quality -> Z= Purchase } \\
\text { decisions -> Y= Customer } \\
\text { satisfaction }\end{array}$ & 0,199 & 0,201 & 0,108 & 1,987 \\
$\begin{array}{l}\text { X2= Brand image -> Z= Purchase } \\
\text { decisions -> Y= Customer } \\
\text { satisfaction }\end{array}$ & 0,193 & 0,161 & 0,112 & 1,972 \\
\hline
\end{tabular}

Hypothesis 6 testing is the indirect effect of Service Quality variables on Customer Satisfaction through Purchase Decisions with a T-statistic value of 1.987> 1.96 which means that the mediation parameters are significant. Then it can be concluded that Service Quality indirectly has a positive effect on Customer Satisfaction through intervening variable purchasing decisions so that hypothesis 6 is accepted.

Hypothesis 7 testing is the indirect effect of the Brand Image variable on Customer Satisfaction through a Purchase Decision with a T-statistic value of 1.982> 1.96 which means that the mediation parameters are significant. Then it can be concluded that Brand Image indirectly has a positive effect on Customer Satisfaction through intervening variable purchasing decisions so that hypothesis 7 is accepted.

\section{CONCLUSION AND SUGGESTION}

Based on the research problem, objectives, hypotheses, and the results of the discussion it can be concluded that: first: service quality has a positive and significant influence on purchasing decisions. These results are in line with the services that Shopee has prepared to convince consumers to buy. Second: brand image has a positive and significant effect on purchasing decisions. This means that buyers assume that Shopee has a good image so far, where if the brand image improves the purchasing decisions will increase. Third: variable service quality, positive and significant effect on customer satisfaction. The fourth variable brand image has a significant positive effect on customer satisfaction. The five service quality variables are proven to have a positive and significant effect on customer satisfaction. Sixth: the purchase decision variable as an intervening variable is proven to have a positive and significant effect on the relationship between service quality and customer satisfaction. Seventh: the purchase decision variable as an intervening variable is proven to have a positive and significant effect on the relationship between brand image on customer satisfaction.

Based on the results of the study it can be interpreted that the selection of the purchase decision variable as an intervening variable is appropriate, this can be proven by the contribution of the influence of service quality and brand image variables on customer satisfaction. 
Based on the research results and conclusions, here are some suggestions to improve purchasing decisions and customer satisfaction through improving service quality and brand image, namely through improving and refining application features and application features, as well as perfecting services such as online payments and increasing shipping speed, to improve image brands so that purchasing decisions and customer satisfaction will also increase.For further researchers, it is expected to be able to examine the variables outside the variables that have been studied in order to obtain more varied results. In addition to adding the number of samples, looking for a wider scope of research.

\section{REFERENCE}

Awara, Nsobiari Festus dan Anyadigibe, Joseph Amaechi. 2014. "The Relationship Between Customer Satisfaction And Loyalty: A Study of Selected Eartries In Calabar, Cross River State". Interdisciplinary Journal of Contemporary Research In Business. Vol 5 No. 9. Pp 157-164

Bedi, M. 2010. "An Integrated Framework for Service Quality, Customer Satisfaction and Behavioral Responses in Indian Banking Industry-a Comparison of Public and Private" Journal of Services Research. Vol. 10 No. 1. Pp. 157-172.

Bielen, Frederic, Nathalie Demoulin. 2007. "Waiting Time Influence on The Satisfaction - Loyalty Relationship in Services, Managing Services Quality". Jurnal of Bussiness and Management. Vol.17 No.2. Pp.174-193

Bontis, Nick., and Lorne D. Booker 2007. "The mediating effect of orgnizational reputation on customer loyalty and service recomendation in banking industry, Management Decion". Vol. 45, No. 9. Pp 1426-1445.

Chao, Ren-Fang, Tai-Chi Wu, Wei-Ti. 2015. "The Influence of Service Quality, Brand Image, and Customer Satisfaction On Customer Loyalty For Private Karaoke Rooms In Taiwan". The Journal of Global Business Management. Volume 11 No. 1 Pp 59-67

Diyanthini, Ni Putu Dharma dan Ni Ketut Seminari. 2014. "Pengaruh Citra Perusahaan, Promosi, penjualan dan Kualitas Pelayanan Terhadap Kepuasan Nasabah Pada Lpd Desa Pakraman Panjer”. Jurnal Manajemen Universitas Udayana. Vol 13 No. 1. Pp 2850-2867.

Giri, I Gede Wahma Diatmika dan I Made Jatra. 2014. "Pengaruh Promosi dan Citra Terhadap Keputusan Pembelian”. Jurnal Manajemen Universitas Udayana. Vol. 3 No. 11. Pp 3154-3169.

Girifin, Jill. 2005. Customer Loyalty: Menumbuhkan dan Mempertahankan Kesetiaan Pelanggan. Erlangga. Jakarta.

Ghorji, Bagheri Mohammad, dan Sayyed Mohammad Bagheri. 2013. "Examining of Promotional Mix Situation and Relationship Between Promotion Mix Factors with Customer Acquisition in The Bank". Advanced Research in Economic and Management Service AREMS. Vol. 11 April 2013. ISSN 2322- 2360. Pp 261-268

Ghozali, Imam. 2011. Aplikasi Analisis Multivariate Dengan Program IBM SPSS 19 Edisi Kelima. Universitas Diponegoro. Jakarta.

Gounaris, Spiros P., Vlassis Stathakopoulos., and, Antreas D. Athanassopoulos .2003. "Antecedents to perceived service quality: an exploratory study in the banking industry". International Journal of Bank Marketing. Vol. 21 No. 4. Pp 168-190. 
Hafeez, Samraz dan Bakhtiar Muhammad. 2012. "The Impact of Service Quality, Customer Satisfaction \& Loyalty Programs on Customers Loyalty: Evidence from Banking Sector of Pakistan". International Journal of Business and Social Science. Vol. 3 No. 16 Special Issue August 2012. Pp 200-209

Hasan, Ali. 2008. Marketing. Media Pressindo. Yogyakarta.

Hurriyati, R. 2008. Bauran Pemasaran dan Loyalitas Konsumen. Alfabeta.

Bandung.

Indratama, Aditya Bagus dan Yessy Artanti. 2014. "Pengaruh Citra Merek dan Promosi Penjualan Terhadap Keputusan Nasabah Memilih Tabungan Bank Syariah Mandiri". Jurnal Ilmu Manajemen. Vol 2 No. 4. Pp 1261-1272.

Info Bank. 2016. 118 Rating Bank 2016. Majalah Info Bank. Vol. XXXVIII No. 451 Pp 18-23.

Ismajli A., Panajoti VH., dan Fejza LE. 2014. "Customer Satisfaction and Customer Loyalty: Evidence From Banking Sector”. Pakistan Journal of Commerce an Social Sciences. Vol 8 No.2. Pp 331354.

Kotler, Philip. 2000. Marketing Management, The Mellenium Edition. Prentice Hall Internasional, Inc. New Jersey.

dan Gary Amstrong. 2008. Prinsip-Prinsip Pemasaran. Jilid 1. Edisi Keduabelas. Erlangga. Jakarta

dan Keller, Kalen. 2009. Alih Bahasa: Benyamin Molan. Manajemen Pemasaran. Edisi Ketigabelas. Jilid 1. Cetakan Keempat. PT. Indeks. Jakarta.

— dan Keller, Kalen. 2012. Marketing Management $14^{\text {th }}$ edition. Global Edition”.

New Jersey: Perason Prentice Hall.

Lovelock, C dan Wright, L. 2005. Pemasaran Jasa. Alih Bahasa oleh Iswari dan Suryandari. PT Gramedia. Jakarta.

Lupiyoadi, Rambat, 2001. Manajemen Pemasaran Jasa : Teori dan Praktik.

Salemba Empat. Jakarta.

Liu, Tsug-Chi and Li Wei Wu. 2007. "Customer retention and cross-buying in the banking industry: An Integration of service attributes, satisfaction and trust". Journal of Financial Service Marketing. Vol. 12 No. 2. Pp 132-145.

Malhotra, Naresh K. 2009. Riset Pemasaran Pendekatan Terapan Edisi Keempat. Indeks. Jakarta.

Mohamad, Anber Abraheem Ahlash dan Shireen Yaseen Mohammad Alhamadani. 2011. "Service Quality Perspectives and Customer Satisfaction in Commercial Banks Working in Jordan, Middle Eastern Finance and Economics”. Euro Journals Publishing, Inc. Vol 11 No. 14. Pp 60-72.

Onyancha, Grace Kavengi. 2013. "The Impact of Brand Image on Customer Satisfaction and Loyalty: A Case of Kenya Commercial Bank Europea". Jurnal of Business and Management. Vol. 5 No. 
21, 2013. ISNN 2222-2839. Pp 35-39.

Ristanti, Vivi, Mucsin Saggaf Shihab, dan Endi Rekarti. 2011. "Pengaruh Dimensi Kualitas Pelayanan dan Kepuasan Terhadap Loyalitas Pelanggan”. Jurnal Manajemen dan Bisnis Sriwijaya. Vol. 9 No. 17 Juni 2011. Pp 1-12. 